\title{
Proximal renal tubular function in myelomatosis: observations in the fourth Medical Research Council trial* $^{*}$
}

\author{
EH COOPER,${ }^{*}$ MA FORBES,$\dagger$ RA CROCKSON,$\dagger$ ICM MACLENNAN $\dagger$ \\ From the *Unit for Cancer Research, University of Leeds, Leeds LS2 9JT, and the †Department of \\ Immunology, University of Birmingham Medical School, Birmingham B15 2TJ
}

SUMMARY Proximal renal tubular function was studied in 522 consecutive patients entered into the Medical Research Council's fourth myelomatosis trial. Assessment was made at presentation after a $48 \mathrm{~h}$ period of hydration but before administration of chemotherapy. The most common abnormalities in the urine other than light chain proteinuria were raised concentrations of the low molecular weight proteins $\alpha_{1}$-microglobulin and $\alpha_{1}$-acid glycoprotein. These were usually accompanied by increases in urinary $\beta-\mathrm{N}$-acetyl-D-glucosaminidase concentrations. The concentration of these substances in the urine directly correlated with urinary free light chain output. This tubular proteinuria was seen whether or not patients had impaired glomerular function, as assessed by a rise in serum creatinine concentration. Urinary concentrations of retinol binding protein, however, were generally increased only when serum creatinine concentrations were raised. This applied even when there were high concentrations of light chains, $\alpha_{1}$-microglobulin, $\alpha_{1}$-acid glycoprotein, and $\beta$ - $\mathrm{N}$-acetyl-D-glucosaminidase in the urine.

There is therefore a selective tubular proteinuria in myelomatosis which is seen in almost all patients with urinary light chain values $>1 \mathrm{u} / \mathrm{l}$. This proteinuria is generally reversible, when light chains no longer appear in the urine. Patients whose serum creatinine was $>200 \mu \mathrm{mol} / \mathrm{l}$, however, had increased urinary output of retinol binding protein in addition to increased excretion of $\alpha_{1}$-microglobulin, $\alpha_{1}$-acid glycoprotein, and $\beta-\mathrm{N}$-acetyl-D-glucosaminidase. Tubular proteinuria in many of these patients presenting in renal failure persisted even when light chain output was reduced after chemotherapy.

The aetiology of the renal failure in myelomatosis is not fully understood, but the evidence points towards multifactorial causes. In most cases the excretion of light chains in the urine appears to be an essential factor. Nevertheless, many patients excrete large amounts of light chains without any impairment of glomerular filtration rate. ${ }^{2}$ There are several reports of varying degrees of defective reabsorption of low molecular weight proteins by the proximal tubular cells in myelomatosis, as detected by sodium dodecyl sulphate (SDS) polyacrylamide gel electrophoresis of urine ${ }^{34}$ or measurement of one or more low molecular weight proteins in the

\footnotetext{
*Prepared for the Medical Research Council (UK) Working Party on Leukaemia in Adults. (For full list of members of the working party see reference 9. .)
}

Accepted for publication 24 April 1984 urine. ${ }^{56}$ There are accounts of rare cases of Fanconi's syndrome occurring in myelomatosis, which indicate that occasionally severe irreversible global tubular damage can occur. ${ }^{78}$ It is difficult to infer from these studies the probable extent of proximal tubular dysfunction in myelomatosis and its relation to glomerular function for the estimates are influenced by the analytes chosen as indices of disease. Also there are technical problems in determining the total protein load applied to SDS polyacrylamide gels.

This paper analyses the ability of the kidney to reabsorb low molecular weight proteins from the glomerular filtrate in $\mathbf{5 2 2}$ untreated patients admitted to the Medical Research Council's fourth myelomatosis trial. This aspect of tubular function was correlated with the excretion of free light chains and impairment of glomerular filtration. A further 
aspect of proximal tubular state was assessed by measuring the excretion of the tubular lysosomal enzyme $\beta$ - $\mathrm{N}$-acetyl-D-glucosaminidase (E.C.3.2.1.30).

\section{Patients and methods}

\section{PATIENTS}

Between 1 March 1979 and 28 February 1982522 patients with myelomatosis admitted to the fourth MRC myelomatosis trial were assessed at presentation after a $48 \mathrm{~h}$ period of hydration. The criteria for entry were as for the previous MRC trial. ${ }^{10}$ Only patients below the age of 75 were included.

\section{CHEMOTHERAPY}

The chemotherapy trial compared the use of melphalan and prednisone with melphalan, vincristine, and prednisone. Patients presenting in renal failure were also managed on a high fluid intake. Details of these treatments are given elsewhere. ${ }^{9}$

The controls were a group of normal subjects from a survey of industry aged 35-70."

\section{SAMPLE COLLECTION}

Samples of serum and $24 \mathrm{~h}$ urine specimens preserved with $0 \cdot 1 \%$ sodium azide were sent to the trials laboratory, Birmingham, by first class mail. In general, samples arrived within $24 \mathrm{~h}$ of despatch. The material was stored at $-20^{\circ} \mathrm{C}$ until analysis. The sodium azide in the concentration used does not inhibit the $\beta$ - $\mathrm{N}$-acetyl-D-glucosaminidase assay.

\section{LABORATORY ASSAYS}

A centrifugal analyser (Instrumentation Laboratories UK Ltd) was used for the following assays: serum and urine creatinine (Jaffé reaction); total serum protein (biuret reaction). Total trichloroacetic acid precipitable protein was assessed in urine samples by the biuret reaction.

\section{SPECIFIC PROTEIN MEASUREMENTS}

Urine free $\kappa$ and $\lambda$ light chains were assessed using specific sheep antisera which did not react with light chain bound to heavy chain. These were prepared by AR Bradwell and RL Drew in the Department of Immunology, University of Birmingham. They were used in radial immunodiffusion assays ${ }^{12}$ with $3 \%$ $(\mathrm{wt} / \mathrm{vol})$ polyethylene glycol 6000 in agarose. $\kappa$ and $\lambda$ standards were prepared from the urine of several patients with myelomatosis without high molecular weight proteinuria by means of gel permeation and ion exchange chromatography. Each standard was made of a mixture of equal amounts (as assessed by optical density) of purified $\kappa$ and $\lambda$ light chains from several patients. The amount of protein in the $\kappa$ and $\lambda$ standards was assessed by the Kjeldahl method.

Results are expressed as units, where one unit is equivalent to $1 \mathrm{~g}$ of standard. Units are used because free light chains from individual patients vary in their degree of polymerisation and antigenicity.

The following proteins were measured by radial immunodiffusion using antisera and standards from various sources: serum and urine $\alpha_{1}$-microglobulin, urine retinol binding protein, and albumin (Behringwerke, Marburg, FDR); $\alpha_{1}$-acid glycoprotein (University of Birmingham). The proteins were measured in unconcentrated urine.

The urine proteins were corrected for urine concentration by presenting all results as milligrams or units of protein per gram of creatinine ( $\mathrm{g} \mathrm{Cr}$ ).

SDS polyacrylamide gel electrophoresis was performed using a discontinuous system after Laem$\mathrm{mli}^{13}$ incorporating $0.1 \%(\mathrm{wt} / \mathrm{vol})$ sodium dodecyl sulphate in a vertical slab apparatus. The running gels contained $12 \% \mathrm{wt} / \mathrm{vol}$ acrylamide. Unconcentrated urine containing $10-20 \mu \mathrm{g}$ of protein was applied to the gel. The gels were stained with PAGE blue 83 (BDH).

Urine $\beta-\mathrm{N}$-acetyl-D-glucosaminidase was measured by a fluorimetric method using a 4-methylumbelliferone substrate as described elsewhere $^{14}$; 1 unit of $\beta$ - $\mathrm{N}$-acetyl-D-glucosaminidase activity is that which will release $1 \mathrm{nmol}$ of substrate $/ \mathrm{h} / \mathrm{mmol}$ urine creatinine. Twelve units was taken as the upper limit of normal. The 4methylumbelliferone substrate was bought from Koch-Light Laboratories, Colnbrook, Berks.

All measurements of urinary $\alpha_{1}$-microglobulin, $\alpha_{1}$-acid glycoprotein, $\quad \beta$ - $\mathrm{N}$-acetyl-D-glucosaminidase, retinol binding protein and creatinine were made in the Unit for Cancer Research, University of Leeds; all other analyses were made in the Department of Immunology, University of Birmingham.

\section{PICTORIAL PRESENTATION}

For simplicity the data points in the Figures have been restricted to about the first 30 patients taken sequentially who fell into the various class intervals of serum creatinine and light chain excretion subsets.

\section{Results}

Throughout the study arbitrary groups were used for convenience when comparing different degrees of renal involvement in myelomatosis. Three arbitrarily defined subsets were created with respect to serum creatinine to take into account the effects of impaired glomerular filtration: (1) patients with a serum creatinine $<130 \mu \mathrm{mol} / \mathrm{l}$; (2) those with a 
Table 1 Urinary light chain concentration and serum creatinine at presentation

\begin{tabular}{lcccc}
\hline $\begin{array}{l}\text { Urinary light chain } \\
\text { concentration }(\text { u/l) }\end{array}$ & \multicolumn{5}{l}{$\begin{array}{l}\text { No of patients with serum creatinine } \\
\text { concentration }(\mu \mathrm{mol} / \mathrm{l}):\end{array}$} \\
\cline { 2 - 5 } & $<130$ & $130-199$ & $>200$ & $>400$ \\
\hline$>1$ & 83 & 53 & 75 & $(38)$ \\
$0.04-1$ & 124 & 47 & 19 & $(7)$ \\
$<0.04$ & 102 & 16 & 3 & $(1)$ \\
Total & 309 & 116 & 97 & $(46)$ \\
\hline
\end{tabular}

Assessment was made before chemotherapy but after rehydration.

small rise of serum creatinine 130-199 $\mu \mathrm{mol} / \mathrm{l}$; (3) those with a serum creatinine $\geqslant 200 \mu \mathrm{mol} / \mathrm{l}$. A serum creatinine concentration of $200 \mu \mathrm{mol} / \mathrm{l}$ was chosen as a cut off value because survival rates of patients with values above and below this value differed considerably. A detailed analysis of the level of serum creatinine and light chain excretion in patients with creatinine $>200 \mu \mathrm{mol} / \mathrm{l}$ has been presented elsewhere. ${ }^{9}$ Three subsets were also made for light chain excretion: $(a)<0.04 \mathrm{u} / \mathrm{g} \mathrm{Cr}$ (this is the 95th percentile for polyclonal $\kappa$ light chain excretion in healthy subjects for this laboratory); (b) $0.04-1.0 \mathrm{u} / \mathrm{g} \mathrm{Cr}$, and $(c)>1.0 \mathrm{u} / \mathrm{g} \mathrm{Cr}$. The division between $(b)$ and (c) was chosen arbitrarily after inspection of the distribution of the data.

\section{RELATION OF URINARY LIGHT CHAIN}

CONCENTRATION AND TYPE TO RENAL FAILURE The distribution of serum creatinine and light chain excretion after hydration but before chemotherapy in 522 patients with myelomatosis is shown in Table 1. The probability of the patients presenting with

Table 2 Distribution of light chain proteinuria according to paraprotein type and serum creatinine

\begin{tabular}{|c|c|c|c|c|}
\hline \multirow{2}{*}{$\begin{array}{l}\text { Amount of free } \\
\text { light chain in } \\
\text { urine }(u / g C r)\end{array}$} & \multirow{2}{*}{$\begin{array}{l}\text { Paraprotein } \\
\text { type }\end{array}$} & \multicolumn{3}{|c|}{ Serum creatinine ( $\mu \mathrm{mol} / \mathrm{l})$} \\
\hline & & $<130$ & $130-199$ & $>200$ \\
\hline $0 \cdot 04-1$ & $\begin{array}{l}\lambda \\
\lambda+ \\
\kappa \\
\kappa+\end{array}$ & $\begin{array}{r}1 \\
28 \\
5 \\
88\end{array}$ & $\begin{array}{r}1 \\
9 \\
4 \\
28\end{array}$ & $\begin{array}{r}0 \\
6 \\
3 \\
10\end{array}$ \\
\hline $1-10$ & $\begin{array}{l}\lambda \\
\lambda+ \\
\kappa \\
\kappa+\end{array}$ & $\begin{array}{r}6 \\
23 \\
6 \\
27\end{array}$ & $\begin{array}{r}2 \\
8 \\
6 \\
18\end{array}$ & $\begin{array}{r}0 \\
17 \\
5 \\
24\end{array}$ \\
\hline Total & $\begin{array}{l}\lambda \\
\lambda+ \\
\kappa \\
\kappa+\end{array}$ & $\begin{array}{r}4 \\
9 \\
1 \\
9 \\
210\end{array}$ & $\begin{array}{r}9 \\
2 \\
2 \\
5 \\
95\end{array}$ & $\begin{array}{r}9 \\
7 \\
10 \\
3 \\
94\end{array}$ \\
\hline
\end{tabular}

$\lambda=$ pure $\lambda$ light chain disease.

$\kappa=$ pure $\kappa$ light chain disease.

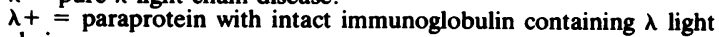
chain.

$\kappa+=$ paraprotein with intact immunoglobulin containing $\kappa$ light chain.
Table 3 Frequency of raised urinary $\alpha_{1}$-microglobulin $(>15 \mathrm{mg} / \mathrm{g} \mathrm{Cr})$ at presentation according to paraprotein type and serum creatinine

\begin{tabular}{llll}
\hline Paraprotein type & \multicolumn{3}{l}{ Serum creatinine $(\mu \mathrm{mol} / \mathrm{l})$} \\
\cline { 2 - 4 } & $<130$ & $130-199$ & $>200$ \\
\hline IgA $\kappa$ & $30(59)$ & $15(20)$ & $12(12)$ \\
IgA $\lambda$ & $5(5)$ & $12(13)$ & $11(11)$ \\
IgG $\kappa$ & $64(121)$ & $20(30)$ & $20(21)$ \\
IgG $\lambda$ & $39(57)$ & $15(15)$ & $11(11)$ \\
IgD $\kappa$ & $1(1)$ & - & - \\
IgD $\lambda$ & $4(4)$ & - & $4(4)$ \\
$\kappa$ only & $10(12)$ & $12(12)$ & $19(19)$ \\
$\lambda$ only & $10(11)$ & $12(12)$ & $9(9)$ \\
None & $5(13)$ & $2(2)$ & - \\
\hline
\end{tabular}

Numbers of patients with $\alpha_{1}$-microglobulin $>15 \mathrm{mg} / \mathrm{g} \mathrm{Cr}$ are shown, with the total number of patients in each group in parentheses.

renal impairment (serum creatinine $>200 \mu \mathrm{mol} / 1$ after correction of possible dehydration) was 0.34 when the urinary light chain excretion was $>1 \mathrm{u} / \mathrm{g}$ $\mathrm{Cr}$. By contrast, the probability was only 0.023 when the excretion was $<0.04 \mathrm{u} / \mathrm{g} \mathrm{Cr}$.

A raised serum creatinine concentration occurred as frequently in patients with $\kappa$ light chain proteinuria as in those with $\lambda$ light chain proteinuria (Table 2).

\section{ANALYSIS OF TUBULAR PROTEINURIA}

$\alpha_{1}$-microglobulin (MW $27 k d a$, peptide content $80 \%$, pI 4.3-4.8)

The frequency of a raised $\alpha_{1}$-microglobulin in the urine $(>15 \mathrm{mg} / \mathrm{g} \mathrm{Cr})$ in the main myelomatosis immunoglobulin types is shown in Table 3 . This is subdivided according to light and heavy chain class in the serum and serum creatinine concentration. From 522 patients studied at presentation 357 (68.4\%) had raised $\alpha_{1}$-microglobulin concentrations ( $>15 \mathrm{mg} / \mathrm{g} \mathrm{Cr}$ ).

The relation between the concentrations of free light chain and $\alpha_{1}$-microglobulin in urine of patients with both normal and raised serum creatinine concentrations is shown in Fig. 1. Urinary $\alpha_{1-}$ microglobulin increased as the amounts of free light chain increased. The Spearman correlation coefficient for the urinary $\alpha_{1}$-microglobulin and free light chain concentration was $r=0.64$ in 247 patients with normal serum creatinine concentrations $(<130 \mu \mathrm{mol} / \mathrm{l})$ (Table 4$)$. There was no significant difference in the range of urinary $\alpha_{1}$ microglobulin excretion between patients with free $\kappa$ and those with free $\lambda$ light chain proteinuria. Crossed immunoelectrophoresis showed that $\alpha_{1-}$ microglobulin was not bound to free $\kappa$ or $\lambda$ light chains. Renal failure, as assessed by a raised serum creatinine concentration, resulted in a significant increase in urinary $\alpha_{1}$-microglobulin concentration 


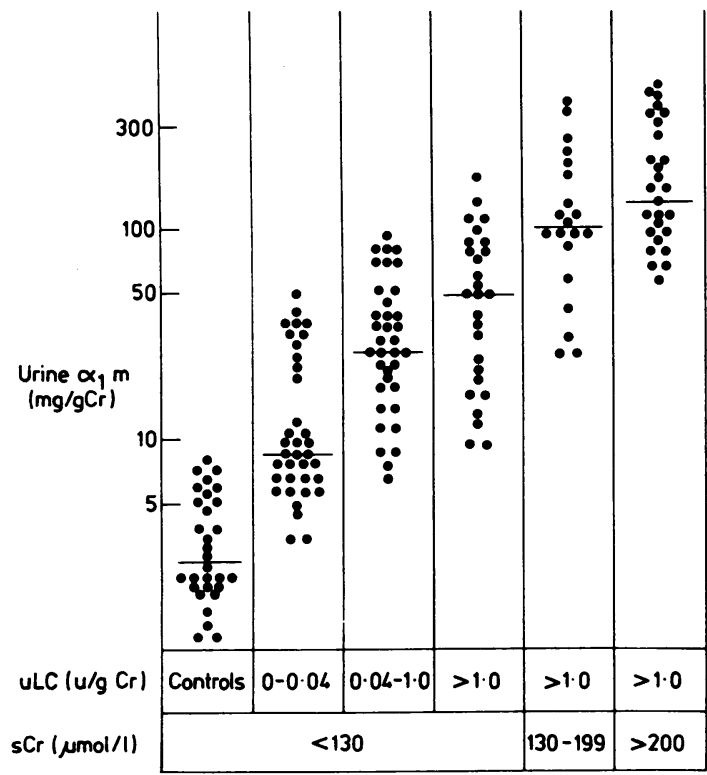

Fig. 1 Relations of urinary $\alpha_{1}$-microglobulin $(\alpha, m)$ and light chain excretion $(u L C)$ and serum creatinine $(s C r)$ in myelomatosis. Median values indicated by horizontal bars.

compared with patients with equivalent levels of light chain output with normal serum creatinine (Table 5).

$\alpha_{1}$-acid glycoprotein (MW $41 \mathrm{kda}$, peptide content $58 \%, \mathrm{pI} 2 \cdot 7$ )

The excretion of $\alpha_{1}$-acid glycoprotein in the urine (Fig. 2) showed a similar correlation with the concentration of free light chains to that seen with $\alpha_{1-}$ microglobulin (Table 3 ). In patients excreting light chains at a concentration of $>1 \mu \mathrm{g} / \mathrm{g} \mathrm{Cr}$ no secondary effect of renal failure was seen (Fig. 2 and Table 5). Patients with high serum concentrations of $\alpha_{1}$-acid glycoprotein $(>2.0 \mathrm{~g} / \mathrm{l})$, however, tended to show higher urinary $\alpha_{1}$-acid glycoprotein excretions (Fig. 2).
Table 5 Effect of renal failure on the excretion of urinary proteins in patients with light chain output $>1 \mathrm{u} / \mathrm{g} \mathrm{Cr} . \chi^{2}$ for trend of rise in urinary output with increase in serum creatinine

\begin{tabular}{llll}
\hline & \multicolumn{1}{c}{$x^{2}$} & $p$ & $n$ \\
\hline$\alpha_{1} \mathbf{m}(\mathrm{mg} / \mathrm{g} \mathrm{Cr})$ & 14.8 & 0.0002 & 106 \\
AGP (mg/g Cr) & 0.2 & 0.63 & 106 \\
RBP (mg/g Cr) & $14 \cdot 1$ & 0.0017 & 19 \\
NAG (u/mmol Cr) & 0.118 & 0.73 & 103 \\
\hline
\end{tabular}

For abbreviations see Table 4 .

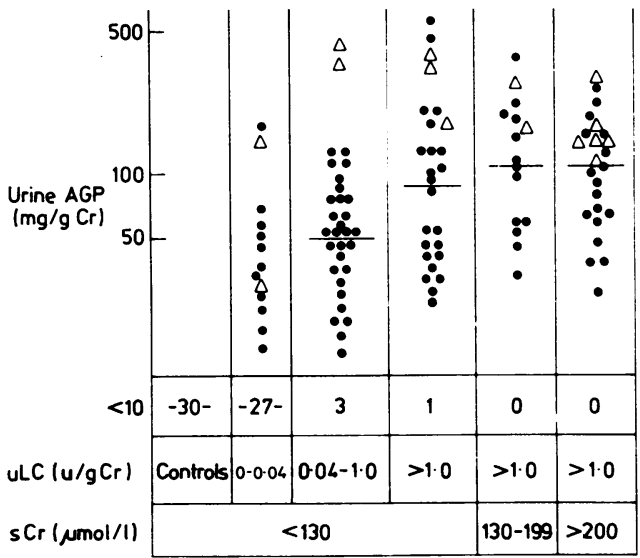

Fig. 2 Relations of urinary $\alpha_{1}$-acid glycoprotein (AGP) and light chain excretion ( $u L C)$ and serum creatinine (sCr) in myelomatosis. $\triangle=$ patients with a serum $A G P>2 \mathrm{~g} / \mathrm{l}$. Median values indicated by horizontal bars.

Retinol binding protein (MW $21 \mathrm{kda}$, peptide content $100 \%$, pI $4 \cdot 7-4 \cdot 8$ )

The distribution of retinol binding protein excretion in the various subsets of the patients in the study is shown in Fig. 3. The normal values of urinary retinol binding protein were below the detection limits of the assay in the presence of normal serum creatinine concentrations. Retinol binding protein excretion in the urine, unlike that of $\alpha_{1}$-microglobulin and $\alpha_{1-}$ acid glycoprotein, only occasionally reached detect-

Table 4 Correlation between urinary light chain output and the concentrations of other urinary proteins in patients with serum creatinine $<130 \mu \mathrm{mol} / \mathrm{l}$

\begin{tabular}{|c|c|c|c|c|}
\hline & \multicolumn{4}{|c|}{ Light chain $v$} \\
\hline & $\alpha_{1} m$ & $A G P$ & $R B P$ & $N A G$ \\
\hline $\begin{array}{l}\text { Spearman } \\
\text { correlation coefficient (r) } \\
n \text { Significance }(p)\end{array}$ & $\begin{array}{l}0.64 \\
247 \\
<0.0001\end{array}$ & $\begin{array}{c}0.64 \\
248 \\
<0.0001\end{array}$ & $\begin{array}{l}0.16 \\
96 \\
>0.1\end{array}$ & $\begin{array}{c}0.39 \\
245 \\
<0.0001\end{array}$ \\
\hline
\end{tabular}

$\alpha, \mathrm{m}=\alpha_{1}$-microglobulin.

AGP $=\alpha_{1}$-acid glycoprotein.

NAG $=\beta$-N-acetyl-D-glucosaminidase.

$\mathbf{R B P}=$ retinol binding protein. 


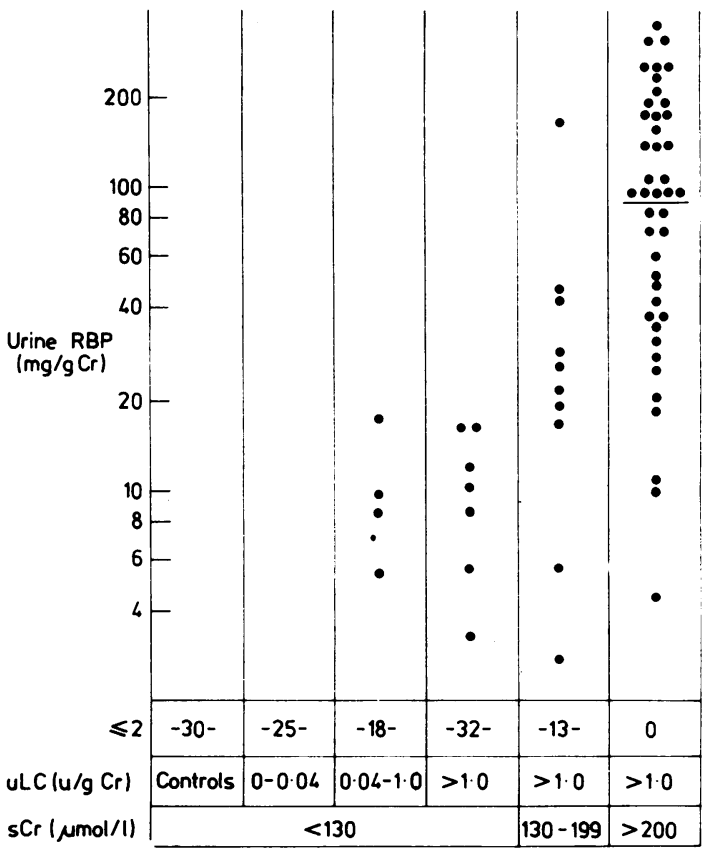

Fig. 3 Relations of urinary retinol binding protein $(R B P)$ and light chain excretion ( $u L C)$ and serum creatinine in myelomatosis. Median values indicated by horizontal bars.

able concentrations, even where there was increased free light chain excretion, provided that the glomerular filtration was normal (Fig. 3, Table 3). There was, however, a pronounced accentuation of retinol binding protein excretion in patients with raised serum creatinine concentrations (Fig. 3, Table 4).

Albumin (MW 66 kda, peptide content 100\%, pI 4.1)

The concentration of urine albumin was $>1 \mathrm{~g} / \mathrm{g} \mathrm{Cr}$ in 117 of 118 patients taken at random from the various subgroups; moderate to severe increases of serum creatinine were present in 25 of these patients at the time of measurement. There was no significant relation between albumin excretion and that of light chain or other low molecular mass proteins.

SDS polyacrylamide gel electrophoresis of the urine SDS polyacrylamide gel assessment of the urine from patients with a total proteinuria of $>1 \mathrm{~g} / \mathrm{g} \mathrm{Cr}$ showed that the predominant pattern was that of a monomer or dimer light chain with a low molecular weight (tubular) proteinuria. A mixed tubular and glomerular pattern with protein bands $>70 \mathrm{kda}$ molecular weight was present in 54 of 522 patients $(10.3 \%)$. A similar proportion (10 of 106 patients)

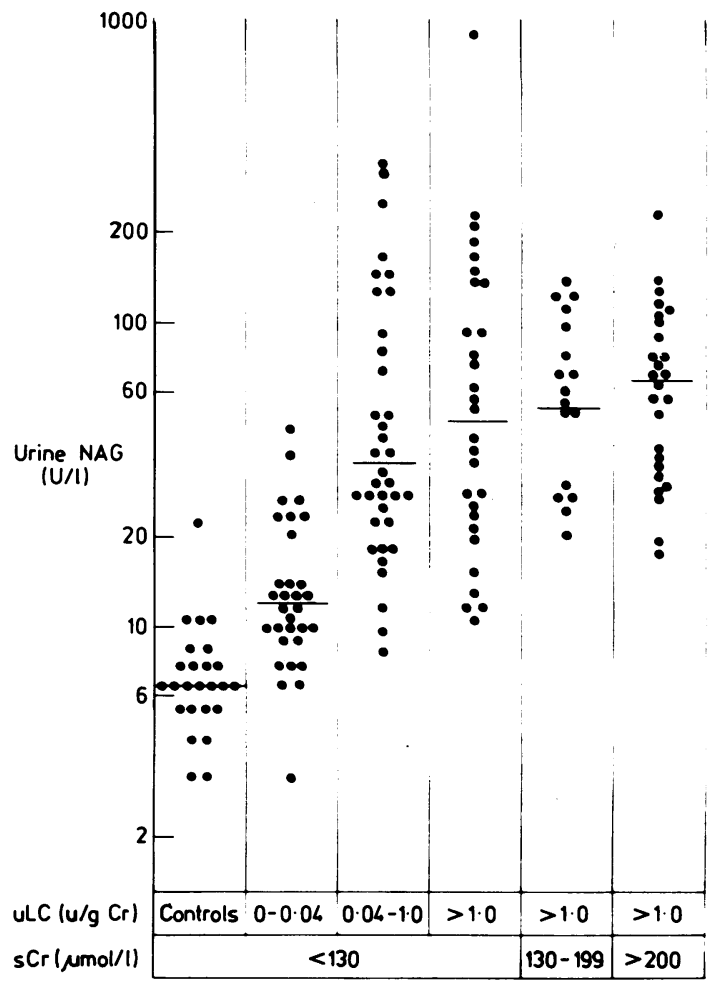

Fig. 4 Relations of urinary $\beta$ - $N$-acetyl- $D$ glucosaminidase (NAG) activity and light chain excretion ( $u L C)$ and serum creatinine in myelomatosis. Median values indicated by horizontal bars.

with serum creatinine concentrations $>200 \mu \mathrm{mol} / \mathrm{l}$ at presentation had a mixed glomerular and tubular pattern.

\section{$\beta$ - $N$-acetyl-D-glucosaminidase}

$\beta$-N-acetyl-D-glucosaminidase activity tended to rise when light chains were present in the urine (Fig. 4 , Table 4). Urinary values were not augmented further in those patients with increased serum creatinine concentrations (Table 5).

\section{Discussion}

The relation of light chain excretion and renal failure is discussed elsewhere ${ }^{16-19}$ and in a separate paper-relating to 80 patients who presented with serum creatinine values above $200 \mu \mathrm{mol} / \mathrm{l}$ in this trial. ${ }^{9}$ Here we describe renal tubular dysfunction in myelomatosis. The clinical tests of tubular function such as urine concentration and acidification and the presence of aminoaciduria reflect the behaviour of distal tubules. In this study we used indicators of proximal tubular function, which are more sensitive 
to change than tests of distal tubular function. In 60 cases of myelomatosis investigated by Virella $e \mathrm{al}^{4}$ using SDS polyacrylamide gel electrophoresis all patients with predominantly tubular proteinuria were also excreting light chains.

In this study almost every patient with monoclonal free light chain excretion (392/399; $98 \cdot 2 \%)$ had impaired reabsorption of $\alpha_{1}$-microglobulin and $\alpha_{1}$-acid glycoprotein, and this was generally accompanied by increased $\beta$-N-acetyl-D-glucosaminidase activity in the urine.

There was some correlation between the amount of $\alpha_{1}$-microglobulin and light chain excreted by patients with serum creatinines $<130 \mu \mathrm{mol} / \mathrm{l}(1.47$ $\mathrm{mg} / 100 \mathrm{ml}$ ), but the extent of the blockade of $\alpha_{1-}$ microglobulin reabsorption varied between patients with similar amounts of light chain in the urine. Free $\kappa$ and $\lambda$ light chains appeared to exert a similar effect on the reabsorption of $\alpha_{1}$-microglobulin. In patients with normal serum creatinine values the serum concentration of $\alpha_{1}$-microglobulin was independent of the concentration of IgG paraprotein. By contrast, in IgA myelomatosis the blood concentrations of $\alpha_{1}$-microglobulin tend to be raised due to the binding of this protein to IgA." Crossed immunoelectrophoresis shows that the plasma contains both bound and free $\alpha_{1}$-microglobulin. Urine contains only free $\alpha_{1}$-microglobulin. As with other low molecular mass proteins $\alpha_{1}$-microglobulin is removed from the blood by glomerular filtration followed by reabsorption and catabolism by the proximal renal tubules. ${ }^{20} \alpha_{1}$-acid glycoprotein is not normally detected by radial immunodiffusion in unconcentrated urine, under the conditions of our assay. Its presence in the urine is influenced by two main factors: proximal tubular dysfunction and the concentration in blood. High concentrations of $\alpha_{1}$-acid glycoprotein in the blood are part of an acute phase reaction to infection, other inflammatory disease, or extensive neoplasia. ${ }^{21} \mathrm{~A}$ rise of the excretion of $\beta$-N-acetyl-D-glucosaminidase, a lysosomal enzyme originating in the proximal tubular cells, ${ }^{15}$ is a second characteristic feature of free light chain proteinuria. The filtration of free light chains by the glomeruli appears to cause little disturbance of the filtration and reabsorption of retinol binding protein. Similarly, in a study of 21 patients with myelomatosis and free light chains in the urine only four of them had slight increases of $\beta_{2}$-microglobulin excretion.22

The selective character of the tubular proteinuria as described above is found in patients with normal serum creatinine concentrations. A change in the pattern of tubular proteinuria usually occurs in patients with myelomatosis in whom there has been a fall of glomerular filtration rate. Retinol binding protein then appears at detectable concentrations in the urine and the increased $\beta$ $\mathrm{N}$-acetyl-D-glucosaminidase excretion persists. Apart from being of lower molecular mass than $\alpha_{1}$-microglobulin and $\alpha_{1}$-acid glycoprotein, retinol binding protein is a pure peptide. However, Scarpioni et $a^{5}$ have reported that the reabsorption of lysozyme, a basic non-glycosylated protein, is inhibited by light chains. This suggests the relative positive charge of $\alpha_{1}$-microglobulin and $\alpha_{1}$-acid glycoprotein is not the reason for impairment of their reabsorption. The almost universal association of impaired $\alpha_{1}$-acid glycoprotein and $\alpha_{1}$-microglobulin reabsorption with light chain proteinuria makes it unlikely that this is a physicochemical effect produced by light chains of a particular range of $\mathrm{pI}$. Also this effect is seen with cationic and anionic light chains ${ }^{23}$ and is common to $\kappa$ and $\lambda$ chains. Hence the effect of the dimer formation, frequent in $\lambda$ chains, does not appear to be an important factor. Nonselective tubular proteinuria is a common phenomenon and can be produced by drugs, ${ }^{24}$ upper urinary tract infection, or in response to burn injury or acute shock syndromes ${ }^{25} 26$ without any increase of serum creatinine above the normal range. During the recovery phase from these lesions the non-selective tubular dysfunction changes to a selective tubular dysfunction, exhibiting selectivity similar to that caused by the light chains. But light chains are not usually detectable in high concentrations $(>0.04 \mathrm{u} / \mathrm{g}$ creatinine) during the recovery phase of these diseases. The reabsorption of protein by proximal tubules is temporarily blocked by infusion of the basic amino acids lysine, and arginine. ${ }^{27}$ In rats lysozyme and cytochrome $C$ compete for endocytic reabsorption by the tubular cells ${ }^{28}$; both these proteins are strongly basic. Permanent proximal tubular dysfunction is a feature of cadmium poisoning, ${ }^{29}$ chronic post-infective interstitial nephritis, and various rare disorders such as Fanconi's syndrome. Partial loss of tubular resorption for low molecular weight proteins can accompany the glomerular lesion in diabetes and hypertensive glomerulosclerosis. $^{3}$

This large series of patients has not confirmed the impression that $\lambda$ light chains are more nephrotoxic than $\kappa$ light chains. ${ }^{2}$ However, high values of free light chain excretion in the urine are most frequent in pure $\lambda$ light chain disease. This may explain the findings of Scarpioni et al, ${ }^{5}$ who found the greatest inhibition of reabsorption of low molecular mass when the light chain was of the $\lambda$ type.

The raised urinary $\beta$ - $N$-acetyl-D-glucosaminidase activity reflects an increased turnover and excretion of lysosomal enzymes in the proximal tubular cells. Atrophy of the proximal tubules is the prob- 
explanation of the decreasing $\beta$ $\mathrm{N}$-acetyl-D-glucosaminidase concentrations in persistent renal failure in myelomatosis.

The factors which precipitate renal failure in myelomatosis have been discussed in detail and include: dehydration; intravenous pyelography; precipitation of Tamm Horsfall protein, light chains, and other material to form casts; hypercalcaemia; pyogenic infection; and amyloid deposition..$^{79}$ Our current studies indicate that most if not all light chains are capable of inducing selective tubular dysfunction. We have little evidence that patients progress to renal failure because their light chains are more toxic than those of patients in whom the serum creatinine remains normal. The selective tubular dysfunction may facilitate development of dehydration and other factors listed above and so predispose to the development of renal failure. Our previous report ${ }^{y}$ has shown that continued high fluid intake can control and in many cases improve glomerular function and reduce the serum creatinine concentrations to normal limits in patients with persistent light chain proteinuria. This underlines the multifactorial nature of events leading to renal failure. Further studies are required to show the precise way in which these factors interact.

\section{References}

' Clyne DH, Pollak VE. Renal handling and pathophysiology of Bence Jones proteins. Contrib Nephrol 1981;24:78-87.

${ }^{2}$ Solomon K. Bence Jones proteins: Malignant or benign? $N$ Engl J Med 1982;306:605-7.

${ }^{3}$ Boesken W. Die tubulare Proteinurie. Klin Wschr 1975;53: 473-9.

${ }^{4}$ Virella G, Pires MT, Coehlo IM. Analytical characterization of the urinary proteins from sixty patients with monoclonal gammopathies. Clin Chim Acta 1974; 50:63-75.

${ }^{5}$ Scarpioni L, Ballochi S, Bergonzi G, et al. Glomerular and tubular proteinuria in myeloma: Relationship with Bence Jones proteinuria. Contrib Nephrol 1981;26:89-102.

- Smithline N, Kassirer JP, Cohen JJ. Light chain nephropathy: tubular dysfunction and light chain proteinuria. $N$ Engl J Med 1976;294:71-4.

' Finkel PN, Kronenberg K, Pesce AJ, Pollak VE, Pirani CL. Adult Fanconi syndrome, amyloidosis and marked K-light chain proteinuria. Nephron 1973;10:1-21.

"Maldonado JE, Velosa JE, Kyle RA, Wagoner RD, Holley KE, Salassa RM. Fanconi syndrome in adults: A manifestation of latent form of myeloma. Am J Med 1975;58:354-64.
${ }^{9}$ MacLennan ICM, Falconer-Smith J, Crockson RA, et al. Analysis and the management of renal failure in the MRC IVth Myelomatosis trial. Br Med J 1984;288:1411-6.

${ }^{10}$ Medical Research Council. Treatment comparisons in the third MRC myelomatosis trial. Br J Cancer 1980;42:823-30.

" Yu H, Yanagisawa Y, Forbes MA, Cooper EH, Crockson RA MacLennan ICM. Alpha-1-microglobulin: an indicator protein for renal tubular function. J Clin Pathol 1983;36:253-9.

${ }^{12}$ Mancini G, Carbonara AO, Heremans JF. Immunological quantitation of antigens by single radial diffusion. Immunochemis try $1965 ; 2: 235-54$.

${ }^{13}$ Laemmli UK. Cleavage of structural proteins during the assembly of the head of bacteriophage T4. Nature 1970;227:680-5.

${ }^{14}$ Leaback DH, Walker PG. The fluorimetric assay of $\mathrm{N}$ acetyl- $\beta$-glucosaminidase. Biochem J 1961;78:151-63.

is Price RG, Dance N, Richards B, Cattell WR. The excretion of $\mathrm{N}$-acetyl- $\boldsymbol{\beta}$-glucosaminidase and $\boldsymbol{\beta}$-galactosidase following surgery to the kidney. Clin Chim Acta 1970;27:65-72.

${ }^{16}$ Martinez-Maldonado M, Yium J, Suki WN, Eknoyan G. Renal complications in multiple myeloma: pathophysiology and some aspects of clinical management. J Chron Dis 1971;24:221-37.

17 de Fronzo RA, Cooke RC, Wright JR, Humphrey RL. Renal function in patients with myeloma. Medicine 1978;57:151-66.

${ }^{18}$ Kyle RA. Multiple myeloma: review of 869 cases. Mayo Clin Proc 1975; 50:29-40.

${ }^{19}$ Bernstein SP, Humes DH. Reversible renal insufficiency in multiple myeloma. Arch Intern Med 1982;142:2083-6.

${ }^{20}$ Berggard I, Ekstrom B, Akerstrom B. $\alpha$ microglobulin. Scand J Clin Lab Invest 1980;40 (suppl):63-71.

${ }^{21}$ Cooper EH, Stone J. Acute phase reactant proteins in cancer. Adv Cancer Res 1979;30:1-44.

${ }^{22}$ Engestrom W, Hyldahl L, Wahgren P. Urinary excretion of $\beta 2$ microglobulin in myeloma patients. Clin Chim Acta 1980; 108:369-74.

${ }^{23}$ Turner R, Cooper EH, Crockson RA. Separation of light chains in myelomatosis by fast protein liquid chromatography. Proteins in biological fuids 1983;31:715-8.

${ }^{24}$ Matthes KJ. Drug induced proteinuria. Contrib Nephrol 1981;24:109-14.

${ }^{25}$ Weise M, Pryfer D, Jaques G, Keller M, Monforf AW. $\beta 2$ microglobulin and other proteins as parameter for tubular function. Contrib Nephrol 1981;24:88-98.

${ }^{26} \mathrm{Yu} \mathrm{H}$, Cooper EH, Settle JAD, Meadows T. Urinary protein profiles after burn injury. Burns 1983;9:339-49.

${ }^{27}$ Morgensen CE, Solling K. Studies on renal tubular protein reabsorption: partial and near complete inhibition by certain amino acids. Scand J Clin Lab Invest 1977;37:477-86.

${ }^{28}$ Baumann K, Cojocel C, Francen-Sieveking M. Inhibition of endocytic lysozyme uptake by cationic proteins in microperfused proximal tubules of rat kidney: Pfugers Arch 1979; 279:(suppl R 12).

${ }^{24}$ Kjellstrom T, Evrin PE, Rahnster B. Dose dependent analysis of cadmium-induced tubular proteinuria. Environ Res 1977; 13:303-17.

Requests for reprints to: Professor EH Cooper, The Unit for Cancer Research, The New Medical School, University of Leeds, Leeds LS2 9JT, England. 